\title{
ПСИХОЛОГІЧНІ ОСОБЛИВОСТІ НАВЧАЛЬНОГО ДІАЛОГУ, ЯКІ ВПЛИВАЮТЬ НА ЕФЕКТИВНІСТЬ ПРОЦЕСУ ФОРМУВАННЯ МОВЛЕННСВОЇ КОМПЕТЕНТНОСТІ СТУДЕНТІВ ПІД ЧАС ВИВЧЕННЯ ІНОЗЕМНИХ МОВ
}

\begin{abstract}
У статті розглянуто психологічні характеристики та особливості навчального діалогу, які розкривають специфіку його організації в навчальній діяльності, показують його можливості в становленні особистісної сфери студентів, у тому зокрема в розвитку їхньої професійно зорієнтованої мовленнєвої компетентності у прочесі вивчення іноземних мов.

Ключові слова: навчальний діалог, навчальна діяльність, психологічні характеристики, особливості, чинники, діалогічна
\end{abstract} ситуачія, мовленнєва компетентність, педагогіка співпраці, рефлексія.

В статье рассмотрены психологические характеристики и особенности учебного диалога, которые раскрывают специфику его организации в учебной деятельности, демонстрируют его возможности в становлении личностной сферь студентов, в том числе и в развитии их профессионально ориентированной речевой компетентности в процессе изучения иностранных языков.

Ключевые слова: учебный диалог, учебная деятельность, психологические характеристики, особенности, факторы, диалогическая ситуация, речевая компетентность, педагогика сотрудничества, рефлексия.

Psychological descriptions of educational dialogue and its features which expose the specific of dialogue organization in educational process, show its possibilities in bringing up personality sphere of students as well as in developing their professionally oriented speech competence in the process of foreign languages learning are considered in the article.

Key words: educational dialogue, educational activity, psychological descriptions, features, factors, dialogic situation, speech competence, pedagogics of collaboration, reflection.

3-поміж тенденцій оновлення освітнього процесу нашої уваги заслуговують ті, які зорієнтовані на вияв суб'єктності педагога і студента в навчальній діяльності. До них можна віднести особистісно зорієнтоване, кооперативне, інтерактивне, розвивальне навчання, які розглядаються в межах педагогіки співпраці (Л. Виготський, М. Каган, В. Ляудіс, Т. Матіс, В. Панюшкін, В. Петровський, Ю. Полуянов, Г. Цукерман, та ін.). Не так давно в просторі педагогіки співпраці почав розроблятися такий напрям, як навчальний діалог, що є складовим компонентом інтерактивного, особистісно зорієнтованого та розвивального навчання.

Особливості навчального діалогу в контексті навчальної діяльності 3 позиції психології розглядали такі науковці: запропоновано концепцію про психічний розвиток особистості через соціальне до індивідуального (Л. Виготський), представлено аналіз закономірностей формування різних психічних функцій у спільній навчальній діяльності (Т. Матіс, Ю. Полуянов, Г. Цукерман), досліджено продуктивні форми спільної навчальної діяльності (В. Ляудіс, І. Негуре, В. Панюшкін); розглянуто особливості особистісного розвитку студента залежно від групових і колективних форм навчальної діяльності (В. Петровський, А. Петровський), викладено основні позиції психологічної теорії спільної діяльності в дослідженнях В. Давидова, Д. Ельконіна, О. Леонтьєва, які розглядали спільну діяльність як детермінанту інтелектуального та особистісного розвитку студента.

Як бачимо, чимало уваги присвячено дослідженню питання навчального діалогу, який розглядається як спосіб, «інструмент» співпраці, що має стати домінантою навчального процесу. Водночас у науковій та методичній літературі недостатньо обгрунтовано функції діалогу у формуванні та розвитку мовленнєвої компетентності студентів ВНЗ під час навчання іноземних мов. Найбільш вивченою $є$ навчальна функція діалогу, а формувальна та розвивальна, особливо у процесі вивченні гуманітарних дисциплін, не отримали всебічного обгрунтування.

Отже, мета сmammi - розглянути особливості навчального діалогу в контексті навчальної діяльності з позиції психології, які сприяють забезпеченню результативності навчального діалогу як засобу формування професійно зорієнтованої мовленнєвої компетентності студентів у процесі вивчення іноземних мов.

Дослідники психологічних характеристик діалогічного мовлення (М. Бахтін, В. Біблер, I. Виготський, Г. Кучинський, Б. Ломов, Б. Поршнєв, В. Скалкін та ін.) визначають такі його особливості:

- репліціювання - обмін репліками, коли відбувається постійний перехід зі слухання на говоріння, зі сприйняття, прогнозування, розуміння на планування та породження власного мовлення;

- $\quad$ рецептивно-продуктивний характер, оскільки кожен співрозмовник може бути в ролі слухача і мовця, у живому діалогічному мовленні обмін репліками відбувається швидко, звідси непідготовленість, спонтанність діалогічного мовлення, що вимагає високої автоматизованості та підготовленості мовного матеріалу; 
- умотивованість: ми завжди говоримо з якоїсь причини, яка визначається або зовнішніми, або внутрішніми стимулами (мотиви партнерів можуть не збігатися, що визначає сам процес і результат спілкування);

- зверненість, адресованість - означає, що ми завжди говоримо 3 кимось, для когось, щоб висловити свою думку, поділитися думками, переконати, довести, запитати, попросити тощо;

- емоційна забарвленість, коли мовець передає свої думки, почуття, ставлення до того, що він говорить;

- ситуативна зумовленість - діалог відбувається в певній ситуації (на занятті слід залучати студентів до навчання іноземної мови через використання реальних ситуацій), ситуативність визначає характер мовної поведінки партнерів, мовне оформлення мовлення;

- двосторонній характер, тобто наявність співрозмовників;

- слухове сприйняття учасників діалогу: важливість інтонації, тембру, тональності тощо, які можуть впливати на семантику слів, змінювати їі або навіть повністю нейтралізувати;

- зорове сприйняття учасників діалогу - особлива роль міміки, жестів та інших паралінгвістичних засобів.

Ефективність навчального діалогу як засобу формування будь-якої компетентності (у нашому випадку мовленнєвої) дослідники (Т. Дикун, Л. Фролова, Н. Пєсняєва та ін.) традиційно пов' язують 3 раціональною організацією навчальної діяльності та діалогових відносин на занятті.

Л. Фролова наголошує на тісному зв'язку між формою організації діалогу (фронтальне навчання, групове навчання, внутрішній діалог) та етапом навчальної діяльності (постановка навчального завдання, пошук розв'язання навчального завдання, моделювання, контроль та оцінка) [5, с. 127].

Ми погоджуємося $з$ висновками Л. Фролової про те, що найбільший потенціал для ефективної організації єдиного комунікативного простору в процесі навчальної діяльності мають груповий (парний) та внутрішній діалоги. Студенти набувають навичок вільного і самостійного вибору відповідних способів розв'язання навчальних завдань, водночас навчаться грамотно організовувати діалогові взаємовідносини, отримують досвід спілкування, а, отже, підвищують рівень мовленнєвої компетентності, що актуально для нашого дослідження.

Н. Пєсняєва поділяє думку щодо ефективності навчальної діяльності 3 використанням засобів навчального діалогу. Відзначає, що правильна організація навчально-виховного процесу реалізується на основі трьох складників:

- потреби самих студентів в опануванні духовного багатства;

- навчальної мотивації;

- презентації навчального завдання, проблеми [4, с. 40].

Т. Дикун уважає, що на ефективність навчальної діяльності може вплинути вправне застосування засобів навчального діалогу, а для правильної організації його на занятті необхідне дотримання таких умов:

- усунення внутрішніх перешкод творчим виявам, мисленню;

- фіксація роботи підсвідомості, збереження навіть випадкових думок;

- надання можливості внутрішньої розминки, освоєння в просторі передбачуваної діалогічної взаємодії;

- розвиток жвавості уяви, широти сприйняття світу співрозмовників;

- допомога студентам у розумінні сенсу і загальної спрямованості діяльності, у якій розвивається їхні особистісні можливості (без такого розуміння багато що сприймається як гра) [1].

Докладне вивчення наукових досліджень А. Зімічева,

Г. Кляцької, Ю. Кулюткіна, В. Марищука, С. Рубінштейна та інших дозволило визначити психологічні чинники, що впливають на зміст і характер діалогічного спілкування:

- процеси сприйняття мовлення співрозмовника і орієнтування в ситуації;

- процеси формування змістового аспекту висловлювання;

- процеси мовного оформлення думки та сприйняття (декодування) реплік партнера по спілкуванню.

Грунтуючись на дослідженнях вищезгаданих науковців, можемо стверджувати, що діалогічне мовлення відбувається за певною схемою. Починаючи діалог, перший його учасник (П1) оцінює комунікативні здібності партнера, орієнтується в ситуації й складає свою програму, що породжує мовлення, аналізує свій мовленнєвий намір і тему. Другий співрозмовник (П2), сприйнявши мовленнєвий твір, аналізує його і вимовляє відповідну репліку, ураховуючи при цьому особистість П1 і ситуацію, власні наміри та мотиви. Таким чином, у діалогічній зв'язці П1-П2 психологічна основа породження висловлювання у співрозмовників неоднакова.

Варто зважити позицію науковців (А. Зімічев, Ю. Кулюткін, В. Марищук, М. Рубінштейн, та ін.) щодо компонентів ситуації, у межах якої відбувається діалог, які знаходяться в постійному русі, що призводить до зміни стимулів протягом першого акту діалогічного спілкування. Ось як це можна відобразити поетапно: 1) оцінка особистості співрозмовника; 2) орієнтування в ситуації; 3) актуалізація досвіду, мовленнєвого наміру, теми; 4) висловлювання П1; 5) висловлювання П2; 6) сприйняття висловлювання П1; 7) оцінювання діяльності ініціатора діалогу; 8) оцінювання 
ситуації; 9) аналіз висловлювання П1 в певній обстановці; 10) актуалізація досвіду, намірів; 11) вибір варіанта реакції.

Такі науковці, як К. Бауш, Н. Гальскова, Г. Єлизаров, О. Шевченко, М. Ляховицький, Ю. Пассов, Г. Перфілов, Г. Яцьковська, та багато інших переконані в тому, що формування діалогічних навичок та вмінь студентів вимагає розв'язання трьох ключових психолінгвістичних завдань: розумового, раціонально-експресивного, комунікативного. Уважаємо за доцільне детально зупинитися на кожному 3 них.

Зміст майбутнього висловлювання визначається розв'язанням розумового завдання. Раціональноекспресивне завдання суб'єкт розв'язує, переходячи від задуму промови до втілення його на основі семантики та синтаксису певної мови. Останній вид завдання - комунікативне завдання, виникає у випадках, коли мовець активно орієнтує своє висловлювання на конкретного слухача і ставить перед собою певну комунікативну мету: проінформувати, повідомити, пояснити, переконати, заспокоїти, 3'ясувати тощо. [3].

Вивчення й аналіз передового педагогічного досвіду дають підстави засвідчити, що урахування психологічних аспектів навчального діалогу дозволяє організувати діяльність таким чином, що діалогічна взаємодія викладача та студента буде сприяти покращенню процесу формування мовленнєвої компетентності студентів під час вивчення іноземних мов. Покращення мовленнєвих навичок та вмінь студентів засобами навчального діалогу в нашому дослідженні буде відбуватися в межах педагогіки співпраці, основна характеристика якої - суб'єктність навчальної діяльності, де суб'єктами виступають викладач і студент.

Ми переконані, що саме знання психологічних особливостей навчального діалогу дозволяє створити необхідні умови для формування суб'єктної позиції студентів: студента 3 навчальною мотивацією, який розуміє цінність пізнання; достатньо активний у ситуації розв'язання нового завдання, здатен самостійно ставити питання, що вимагають розв'язання, знаходити власний спосіб розв'язання проблемного завдання та пояснювати свій вибір дій; здатен до рефлексії, за допомогою якої вираховує власні помилки. Характерними рисами викладача як суб'єкта навчального діалогу ми розглядаємо рефлективність особливого виду - внутрішню діалогічність професійної самосвідомості; здібність до самокомунікації як вияву професійного розвитку, як умову внутрішнього діалогу; рефлексію (самосвідомість та самооцінювання) за принципом «інтерпретації» (результати студентів залежать від власних навчальних дій викладача) [2]. 


\section{Література}

1. Дикун Т. П. Учебный диалог как средство формирования личностно ориентированного знания : дис. ... канд. пед. наук : 13.00.01 / Тамара Петровна Дикун. - Оренбург, 1999. - 213 с. 2. Николаева В. Д. Структурносемантические и прагматические особенности трехчленных диалогических единств в английском языке : автореф. дис. на соискание учен. степени канд. филол. наук: спец. 10.02 .04 «Германские языки»/ В. Д. Николаева. - К., 1987. - 20 с. З. Пассов Е. И. Основы коммуникативной методики обучения иноязычному общению : [Текст] / Е. И. Пассов. - М. : Рус. яз., 1989. - 276 с. 4. Песняева Н. А. Учебный диалог как средство развития речевой деятельности младших школьников : дис. ... канд. пед. наук : 13.00 .01 / Наталья Александровна Песняева. - Москва, 2004. - 214 с. 5. Фролова Л. С. Учебный диалог как организующий инструмент единого коммуникативного пространства системы развивающего обучения : дис. ... канд. пед. наук : 13.00.02 / Любовь Сергеевна Фролова. - Ярославль, 2010. - 346 с. 